\title{
Enzyme Replacement or Supplement Agent
}

National Cancer Institute

\section{Source}

National Cancer Institute. Enzyme Replacement or Supplement Agent. NCI Thesaurus.

Code C29726.

Synthetic enzyme or mixture of enzymes used to replace or supplement enzymes to treat enzyme deficiency or to promote healthy body functions. 